\title{
The Gender Wage Gap in Pakistan: Extent, Trends, and Explanations
}

\author{
Shagufta Yasmin ${ }^{1}$, Muhammad Jamil ${ }^{2}$ and Muhammad Iqbal ${ }^{3}$
}

\begin{abstract}
The gender wage gap has remained one of the most discussed issues globally and persists in almost all countries, either developed or developing. Despite researchers' and policymakers' novel contributions, the wage gap among individuals in society exists. This study focuses on demographic, socio-economic, and job-specific determinants of the gender wage differential. The study also highlights the trend of the wage differential over time for Pakistan. For the empirical analysis, microdata used is retrieved from Labour Force Survey (LFS), covering two decades, 1997-98, 2006-07, and 2017-18. For the analysis, we have applied Oaxaca-Blinder and Neuman-Oaxaca decomposition techniques. The findings of this study determine the wage differential due to differences in characteristics of males and females, such as schooling, experience, work location, whether rural or urban, marital status, employment sector, and occupations by skill levels. Furthermore, it determines the wage differential due to other unobservable differences, often called discrimination against females. Results also show that the wage gap between males and females has increased from $39 \%$ in 1997-98 to $79 \%$ in 2006-07 and $87 \%$ in 2017-18.
\end{abstract}

Keywords: Gender Wage Differential, Discrimination, Oaxaca Decomposition Technique

JEL Classification: C21, D31, I26, J16, J31

\section{Introduction}

The definition of the gender wage gap used here is the difference between males' and females' median earnings compared to the median earnings of males. The job market rewards working females less than males from the start. Although there are equal pay acts, women of every education level and race are still getting less than men. The gender gap issue should be important to everyone. After all, it

\footnotetext{
${ }^{1}$ Shagufta Yasmin is MPhil graduate from School of Economics, Quaid-i-Azam University, Islamabad, Pakistan.

${ }^{2}$ Dr. Muhammad Jamil, Professor of Economics, Ghulam Ishaq Khan Memorial Chair, Kashmir Institute of Economics, The University of Azad Jammu and Kashmir, Muzaffarabad, Pakistan.,

${ }^{3}$ Dr. Muhammad Iqbal, Department of Economics, University of Vienna, Vienna, Austria.

Corresponding author's Email: mjamil@qau.edu.pk
} 
is a crucial issue that must be resolved because it can be very discouraging for working females and the females who will enter the labour market.

Discussion on sustainable economic growth is incomplete without a debate on gender equality. Whether gender-based or not, growing inequality is terrible for a country, as it undermines social cohesion and growth. The International Monetary Fund (IMF) reported that countries with more income inequalities also tend to have wider gender gaps in health, education, participation in the labor market, and representation in respective institutions. The connection among limited opportunities, low wages, and social gender customs all combine to keep females in the poor working category (IMF, 2013).

The study aims to estimate the gender wage gap for three surveys of PSLM (1997-98, 2006-07, and 2018-19). The study shows that the gender wage gap persists and has increased with time, even when females have become more empowered than they were two decades ago. The females earn less than their male counterparts and have limited opportunities, face biases in employment, choose whether and when to bear children, and have a disproportionate share of housework (Gilbert, 1994). It also matters in housing values, as Salari and Javid (2019) found that a 10 percent increase in female labor force participation will increase housing values by 12.5 percent.

Moreover, promoting gender equality and empowering females is the $5^{\text {th }}$ goal of Sustainable Development Goals (SDGs). As per the Global Gender Gap Report 2020, by World Economic Forum, Pakistan has slipped from $112^{\text {th }}$ out of 115 countries in 2006 to $151^{\text {st }}$ out of 153 countries in $2020^{4}$ and was ranked on $148^{\text {th }}$ number in 149 countries in 2018. Global Wage Report 2018/19 (International Labour Organization, ILO) has stated that the bottom 1 percent of wage earners are almost 90 percent female. ${ }^{5}$ However, in Pakistan, article 27 of the constitution states:

"No citizen otherwise qualified for appointment in the service of Pakistan shall be discriminated against in respect of any such appointment on the ground only of race, religion, caste, sex, residence or place of birth"

\footnotetext{
${ }^{4}$ See the Global Gender Gap Report 2020,

https://www.weforum.org/reports/gender-gap-2020-report-100-years-pay-equality

${ }^{5}$ See Global Wage Report $2018 / 19$ by ILO

https://www.ilo.org/global/research/global-reports/global-wage-report/2018/lang--en/index.htm
} 
Unfortunately, this constitution article is only for public sector jobs and does not cover private-sector employment. There is no specific law in the country that deals with discrimination in all employment sectors.

The gender wage gap today has become a significant concern around the world. The wage gap harms females and young girls growing up, making them feel less worthy and powerless. Babcock and Laschever (2003) found that females typically could not demand a high salary and do not negotiate as a man does. Pakistan has been engulfed with a similar problem that unfortunately has not received the same level of attention. The wage differences based on gender is evident more in the private sector and informal market. One of the significant factors that cause the gender disparity in wages is that Pakistan is a maledominated, patriarchal society. Here both the households and the markets are dominated by men, which is why there is discrimination in education and then later in the job market, which significantly affects wages of both genders.

After viewing the pay gap between males and females, the present study aims to have an insight into the gender wage gap for three time periods, 1997-98, 2006-07, and 2017-18 in Pakistan, which comprises almost two decades, for the employees of both genders working in every industry. There will be two main objectives. First, it estimates the magnitude of differences in wages due to Pakistan's demographic, socio-economic, and job-specific variables. Second, it measures the proportion of this difference in different periods.

\section{Review of Literature}

\subsection{Theoretical Approaches to Wage Determination}

The phenomenon of gender inequality has been analyzed by numerous researchers in both developed and developing countries (Nasir, 2002; Farooq and Sulaiman, 2009; Schirle, 2015; Biltagy, 2018; Chakraborty, 2020; Loewenthal and Miaari, 2020; Iwasaki and Ma, 2020; Geleta, 2021). Gender wage differential prevails in all countries as for least developed country Nepal, Koirala (2007) analyzed the wage differential in the manufacturing sector for three time periods 1992, 1997, 2002 and uses the panel data from the census of manufacturing establishment in Nepal. Results showed that there is huge gender wage discrimination against a female in all manufacturing firms either in the private sector or in the government sector. To study the difference in wages in sectors either in private or public, it is important to discuss as Razavi and Habibi (2014) investigated the degree of wage discrimination against females in Iran by using Oaxaca decomposition in both private and public sectors and found low 
participation of females in the labor market, and results suggest that wage differentials in both public and private sectors, is largely due to gender discrimination. Though the presence of gender-based segregation of job can easily be verified empirically with the reality that females generally concentrate in such occupations and sectors which offers fewer wages than the sectors and occupations which are male-dominated.

Generally, factor prices are determined through demand and supply of that factor, likewise, wages are determined by demand and supply of labor. Practically wages are not fully determined by the supply and demand schedule of labor and this is because labor is different from other factors of production.

Modern economic models of discrimination in the labor market on a gender basis have been encouraged by Becker (1957), who attributed this discrimination to employer's tastes. In the model, employers who dislike hiring females or believe that male employees would not like working with females will keep the cost of employing females in mind even with equal productivity of both genders, so they offer low wages to females to cover this cost and this is called "discrimination", which is thus called loss of utility experienced by the employer, by hiring additional women. Becker's model is supporting many econometric models like Oaxaca (1973), which is now the standard model for most of the empirical analysis on gender wage differential.

It is predicted by Becker (1962) that human beings invest in themselves in several ways i.e. incur current costs for future benefits education, on-job training and experiences are all significant expressions of self-investment. Mincer (1962) further supported Becker's (1962) idea of human capital and argued that people invest in human capital till the point, where the marginal return of their investment is equal to marginal cost. Thus, human capital theorists ignored the other aspects of differential including labor market imperfections.

The human capital theory states that there is a concave education-to-earning relationship and diminishing yields to human capital production, but this view has been challenged by various critics, for example, Duraisamy, (2002) and Soderbom et al. (2006). Despite the critiques, the Mincerian function is popular and widely used. The theories discussed in this section had provided an insight into malefemale wage differential. A survey of empirical research from the literature is presented in the next section. 


\subsection{Empirical Evidence}

The gender wage differential was empirically estimated by Oaxaca (1973) and Blinder (1973) who decomposed the earning into two parts: wage differential due to individual characteristics and wage differentials due to the difference in estimated returns of these characteristics or simply discrimination. For example, the first term estimates the wage gap share, which might be due to less experience of females in the labor market, while the second term, unexplained portion of wage differential, shows the returns to experience is different for both genders even having the same level of characteristics. The lower returns to equal observed characteristics of men and women can be taken as discrimination against females. Mincer and Polachek (1974) developed the semi-log earnings function, where the natural $\log$ of individual earnings is a linear function of years of schooling completed, labor market experience, and its square. It was later augmented by other variables by providing a link between theory and evidence and used in almost all wage determination studies.

As mentioned above gender wage gap has two portions, one is explained and the other is an unexplained portion. But the unexplained share of the wage gap is explained by forced discrimination by the employer's side (Hirsch, 2016). Further in Hirsch's study stated that a major portion of the wage gap is unexplained or mysterious and this is sort of monopolistic wage discrimination is reflected in the male and female wage gap, which means, employers, use their power without any kind of preferences. Biltagy (2018) analyzed the gender wage gap using Neuman and Oaxaca (2004) technique for the two time periods, 2006 and 2012 to evaluate the magnitude of the gender wage gap in Egypt. Data showed that there is an improvement in the gender wage gap from $25 \%$ to $21 \%$. There are many determinants of gender wage differentials, like labor force participation by women, differences in characteristics, and many others. Ma (2021) have analysed the gender wage differential in ownership sector of China and found that gender wage gap includes the difference in human capital variables and the discrimination against females which is according to the Oxaca (1973) and Blinder (1973) hypothesises.

The human capital approach that is supply-oriented asserts that due to differences in labor force participation, males are earning more than females. Labour force participation rates only portray an incomplete picture of female's work so to make insight into this matter, the relationship between the work histories of women and the growth of earnings over the life cycle has been discussed by Mincer and Polachek (1974). They broke up post-school investment into three parts. First, due to marriage and childbearing, women less invest in on-job training 
than men. Second, married women have some periods of non-participation in which children are reared and so their skills depreciate. Last, when children start schooling, the period of re-entry to a job with new investment starts. Empirical findings of their analysis are that the home-time to rear children coefficient is negative and is significant for married women indicating depreciation in skills and it is strongest with a greater level of schooling. The coefficient of home-time is also negative for unmarried women but is statistically insignificant. Further current experience is positive and higher than the pre-maternal experience at low levels of schooling.

Further, Polachek (1975) supported the view of Mincer and Polachek (1974) and stated that marriage and the number of children affect labor force participation differently for males and females. Family characteristics, marital status, and length of marriage were regressed on the female to male earnings ratio using census data of 1960 and 1970. The study found that if females and males are equal in labor force participation, marriage length and number of children increase the male-female wage gap. But these results are challenged by Corcoran and Duncan (1979) who used Panel Study of Income Dynamics of Michigan and explicitly measured on-job-training, absenteeism (absence), and self-imposed limitations on job choice. Findings with this detailed history of work, contradicted Mincer and Polachek (1974) results as they found that the rate of returns to labor force attachment was not greater for white men as compared to women.

Hagiwara et al. (2018) stated that in developing countries having more children widens the gender wage gap and in developed countries, more participation in the labor force by women narrow the wage gap between males and females and this might be due to high paying job offers in developed countries. Education is an investment in human capital to give expected returns in the future (Becker, 1964). Education is an important tool to increase economic growth as Denison (1964) examined schooling and its effects on long-run economic growth and results showed that education positively affects economic growth and it also increases the skills and marginal productivity of the labor force. To examine the difference between male and females' rate of investment in Korea, Lee and Ihm (2020) contributed to the literature, and their findings are interesting as females' rate of investment in education is more than males in fields of culture and arts, and there is less increase in females' investment than males' in the fields of law and medicine.

Most of the studies use Mincer (1974) framework, taking the idea that education is a good proxy for human capital because it develops general skills. 
Human capital is taken as a set of skills and abilities, a person attains through the training and experience on the job which increases the individual's value in the job market. According to this theory, an individual's motivation in investing in training is directly related to the time one expects to work over a lifetime (Polacheck, 2004).

According to human capital theory, motivation for investing in training is directly proportional to the expected time of work for one's lifetime period. Polachek (2004) states that human capital theory connects expected labor force participation for a lifetime to one's incentive to obtain marketable training. The acquired training determines earnings potential so one's ability to attain higher earnings is an important factor in obtaining human capital. Similarly, Razavi and Habibi (2014) stated that human capital (quality of labor force) is almost equal and in some cases, greater for women, and decomposition for separate skills suggested that wage discrimination is higher for less-skilled labor as compared to scientists and specialists.

Many empirical studies stated the negative relation between wages and occupational segregation, as female-dominated occupations pay lesser to workers than male-dominated occupations. Such as in the construction industry, there is less participation of females and Shrestha et al. (2020) confirm the steady gender wage difference in the top ten construction industries in the USA. Most of the studies do not focus on all of the three mechanisms (de Ruijter et al., 2003). One mechanism is based on Human Capital Theory, which is about wage differences of male- and female-dominated occupations, based on the human capital differences of individuals (Mincer and Polachek, 1974). Females generally spend more time at home, so they less invest in human capital as compared to men, and therefore employers also invest less in the human capital of female employees. So, it can be stated that to some extent gender wage gap is due to female's tendency to go to work in an occupation with flexible working hours and fewer wage penalties for out-of-work time due to motherhood. So, not only occupational segregation but cultural norms play a role in disadvantaged females in the labor market (Blau, 1996). Another mechanism is about "crowding theory", which describes the wage differences by gender according to restricted access of females to some specific occupations (Bergmann, 1974). The third and last mechanism is about gender bias, which is based on the view that females and males are treated differently.

\subsection{Empirical Evidence from Pakistan}

The gender wage gap exists in almost every country and Pakistan is no exception. In the case of Pakistan, many studies are contributing to the literature 
on the issue of the gender wage gap. Some focus on wage determination and some on gender wage differential through different techniques.

The first comprehensive study (with controlling of selectivity biases) on the gender wage gap for Pakistan was conducted by Ashraf et al. (1993) on this wage gap using the Household Income and Expenditure for two time periods 1979 and 1985-86. Oaxaca (1973), Cotton (1988), and Neumark (1988) methods were used to examine the wage gap and estimates were for all provinces and nine main industrial groups and results showed a significant drop in the gender wage gap and this broad-based occurred in every given industrial group and all provinces.

To check the impact of human capital variables on regular earnings Nasir (2002) and Farooq and Sulaiman (2009) used human capital main variables such as education and experience. The results are the same as other studies; human capital is a device for productivity enhancement because all human capital variables have a significant and positive impact on earnings. Farooq and Sulaiman (2009) further decomposed the wages between female and male workers for Pakistan and found that male workers have the advantage of earning more than female workers.

Further contribution in literature is made by Sabir and Aftab (2007) by examining the extent to which the gender wage gap is different to conditional wage distribution and findings are there is less gender wage gap at the $90^{\text {th }}$ percentile. Some socio-economic and cultural limitation obstructs the female's participation, and females are not different in productivity and if there is no discrimination, females could earn more than men in some cases (Yasin et al., 2010) focused on wage differentials and employment positions by gender in Pakistan.

As females lack behind males in wage perspective, is education a factor of this difference? Qureshi (2012) tried to answer this question by focusing on females' access to education. She focused on less investment in a daughter's education as compared to sons and found that there is less investment in female's education even when education returns are being higher for them. These results indicated that there is a convex education-earning relationship.

\section{Data and Methodology}

\subsection{Data}

Cross-sectional micro-data from Labour Force Survey (LFS), 1997-98, 2006- $07^{6}$, and $2017-18$, is employed for empirical analysis, conducted by the

\footnotetext{
${ }^{6}$ Data was available for 2007-08 also, but not used in the study due to missing of some relevant information.
} 
Pakistan Bureau of Statistics. Labour force statistics is a survey to collect information of the country's civilian labor force through a questionnaire. The data had been collected, with several questions such as education, age, sex, training, migration, employment status, and wages, etc, by asking direct questions in interviews.

However, data used in our study is restricted to individuals whose age is between 15-65 years. To avoid outliers, data is trimmed at 1 percent, this further reduces the number of observations for all three data sets all these statistics are shown in Table 1.

Table 1: Number of survey participants in different categories

\begin{tabular}{lccc}
\hline & $\mathbf{1 9 9 7 - 9 8}$ & $\mathbf{2 0 0 6 - 0 7}$ & $\mathbf{2 0 1 7 - 1 8}$ \\
\hline Total & 113,129 & 224,280 & 272,490 \\
Unemployed/ Not in labour force & 84,599 & 162,068 & 196,171 \\
Employed & 28,530 & 62,212 & 76,319 \\
Between 15-65 age group & 60,126 & 58,247 & 72,678 \\
After deleting missing values & 10,338 & 23,756 & 30,623 \\
After trimming of the data & 10,142 & 23,317 & 30,026 \\
Male & 9,355 & 20,708 & 26,166 \\
Female & 787 & 2,609 & 3,860 \\
\hline
\end{tabular}

Source: Labour Force Survey (LFS)

The present study divides the determinants of gender wage differential into three broad categories which are explained in Table 2 .

Table 2: Determinants of wages

\begin{tabular}{|c|c|c|}
\hline Demographic determinants & Socio-economic determinants & Job-Specific determinants \\
\hline $\begin{array}{ll}\text { - } & \text { Gender } \\
\text { - } & \text { Marital status } \\
\text { - } & \text { Age } \\
\text { - } & \text { Region }\end{array}$ & $\begin{array}{ll}- & \text { Schooling } \\
- & \text { Training } \\
- & \text { Location of residence } \\
\text { - } & \text { Location of work }\end{array}$ & $\begin{array}{ll}\text { - } & \text { Work experience } \\
\text { - } & \text { Employment type } \\
\text { - } & \text { Working hours } \\
\text { - } & \text { Occupation by skill levels }\end{array}$ \\
\hline
\end{tabular}

The description of variables along with notations is given in Table 3 . The natural $\log$ of monthly wages ${ }^{7}$ is used as the dependent variable. Total years of schooling is included in the model from the perspective of human capital theory, however, it is not necessarily a good measure of human capital either, because if education acquired is not utilized in work, it will not increase productivity, whereas any skill or knowledge acquired may enhance productivity just as schooling. For this purpose, training is also included in the analyses as a dummy variable, whether an individual has acquired any type of training or not.

Due to the unavailability of experience information, age is used as a proxy, one reason is that education is not available in completed years but in levels so, due to this reason, a widely used technique to measure the potential experience i.e. (age-

\footnotetext{
${ }^{7}$ The monthly wages are expressed in rupees, calculated by multiplying weekly wages with 4 and dividing yearly earnings by 12 to have all wages in months.
} 
schooling-6) proposed by Mincer is not possible. For the case of Pakistan as Ashraf et al. (1993) raised a point that school enrolment age is not the same in different parts of the country, so the potential experience is not very helpful in the case of Pakistan. Labour force participation of males and females is affected differently by marital Status. Married women have to spend time on childbearing and raising. The marital status is divided into two categories, married or never married. Internal migration is an important variable as according to economic theory based on maximization behavior of individuals, takes migration as an investment in human capital. (Sjaastad, 1962). Migration can be inter and intra-provincial and ruralurban migration but here in our study migration is taken as a binary variable, whether an individual migrated or not. The area in which an individual resides is captured by a dummy variable, 1 if lives in an urban area, 0 otherwise. Four regional control variables are included which are four provinces of Pakistan (Punjab, Khyber Pakhtunkhwa, Sindh, Balochistan).

Table 3: Summary of variables

\begin{tabular}{|c|c|c|}
\hline Variable Name & Notation & $\begin{array}{r}\text { Description } \\
\end{array}$ \\
\hline $\begin{array}{l}\text { Natural Log of } \\
\text { Wages }\end{array}$ & W & $\begin{array}{l}\text { We have used log of monthly wages in our analysis as a dependent variable*. It } \\
\text { includes earnings and bonuses evaluated on monthly basis. These are the earnings of } \\
\text { only paid employees; self-employed persons' earnings are not included. }\end{array}$ \\
\hline Schooling & $\mathrm{SCH}$ & $\begin{array}{l}\text { It is one of the main determinants of earnings as per human capital theory, in this } \\
\text { study schooling is measured in levels completed. It is expected that it has a positive } \\
\text { impact on earnings because it is positively related to productivity. }\end{array}$ \\
\hline $\begin{array}{l}\text { Experience and } \\
\text { Experience } \\
\text { square }\end{array}$ & $\begin{array}{l}\mathrm{EXP} \text { and } \\
\mathrm{EXP}^{2}\end{array}$ & $\begin{array}{l}\text { As there is no information on experience in LFS so, age is used as a proxy for the } \\
\text { experience because of the formula to calculate experience. }\end{array}$ \\
\hline Training & TRA & $\begin{array}{l}\text { According to human capital theory training is also an important factor of productivity, } \\
\text { so the coefficient of training will be positive to earnings. One if a person received any } \\
\text { formal training, zero otherwise. }\end{array}$ \\
\hline Migration & MIG & $\begin{array}{l}\text { Migration is taken as a dummy variable where, one if an individual is migrated, zero } \\
\text { otherwise }\end{array}$ \\
\hline $\begin{array}{l}\text { Work location } \\
\text { dummy }\end{array}$ & WLO & $\begin{array}{l}\text { Urban is taken as a location dummy for analyzing that how much location impacts the } \\
\text { earning structure of both genders, rural is taken as a reference category. }\end{array}$ \\
\hline $\begin{array}{l}\text { Number of } \\
\text { working hours in } \\
\text { a week }\end{array}$ & WHR & $\begin{array}{l}\text { The marginal effect of working hours on labor productivity is increasing. So, working } \\
\text { hours are taken as an input to labor productivity and then one of the determinants of } \\
\text { earnings. }\end{array}$ \\
\hline Marital status & MAR & $\begin{array}{l}\text { This variable is divided into ever married and not married categories and not married } \\
\text { taken as a reference category. }\end{array}$ \\
\hline Enterprise type & PUB & $\begin{array}{l}\text { Enterprise type is included to check whether there is a significant impact of enterprise } \\
\text { type on income or not. Ten categories are defined in LFS, and here in our study, we } \\
\text { take them as Public or Private enterprise categories. } 8\end{array}$ \\
\hline Regional & PUN & Four dummy variables are taken for the provinces (Punjab (PUN); Sindh (SIN); \\
\hline dummies & $\begin{array}{l}\text { SIN } \\
\text { KP }\end{array}$ & Khyber Pakhtunkhawa (KP); Balochistan (BAL), Sindh is the reference category. \\
\hline $\begin{array}{l}\text { Occupations by } \\
\text { Skill levels }\end{array}$ & $\begin{array}{l}\text { BAL } \\
\text { SKL_1 } \\
\text { SKL_2 } \\
\text { SKL_3 } \\
\text { SKL_4 }\end{array}$ & $\begin{array}{l}\text { Four occupational skill levels are included in the analysis as skill level } 1 \text { have } \\
\text { occupations with the lowest skills and skill level } 4 \text { have occupations with the highest } \\
\text { skills. }\end{array}$ \\
\hline
\end{tabular}

${ }^{8}$ See Hyder and Reilly (2005) 
Four skill levels are included as dummy variables, skill level 1, skill level 2, skill level 3, and skill level 4. Skill is defined as the capability to perform the tasks and duties of a given job (PSCO-2015). Nine major Occupations are grouped according to skill levels given in Table 4 . We excluded the 10th category i.e. Armed forces from the analysis due to the smaller number of observations and LFS survey data is not carried out in the areas of the armed forces. In the present analysis, we excluded all those individuals who were not working at the time of the interview and did not fall in any of the occupational categories.

Table 4: Major groups of occupations with skill levels

\begin{tabular}{lc}
\hline Major Groups of Occupations & Skill Level \\
\hline Managers & $3+4$ \\
Professionals & 4 \\
Technicians and Associate Professionals & 3 \\
Clerical Support Workers & 2 \\
Services and Sales Workers & 2 \\
Skilled Agricultural, Forestry and Fishery Workers & 2 \\
Craft and Related Trades Workers. & 2 \\
Plant and Machine Operators, and Assemblers & 2 \\
Elementary Occupations & 1 \\
Armed Forces Occupations & $1+2+4$ \\
\hline
\end{tabular}

Source: Pakistan Standard Classification of Occupations (PSCO) 2015

The summary of non-categorical variables in this study are given in Table 5 for males and Table 6 for females which shows mean wage of Rs.3335 for males and Rs.2665 for females in 1997-98, Rs.6065 for males and 4201 for females in 2006-07 and Rs.18708 for males and Rs.12877 for females in 2017-18 which describes that on the average female are earning almost 20 percent, 30 percent, and 31 percent less than their male counterparts in 1997-98, 2006-07 and 2017-18, respectively.

Among other features of female workers, Table 5 and Table 6 present that, on average, females have one extra year of schooling and one lesser year of experience than their male counterparts - an outcome that supports the Mincer and Polachek (1974) hypothesis for the same cause of the observed male-female wage differentials. Average working hours are less for females as they have to spend time at home (childbearing, household chores, and looking after other family members and issues). The description analysis provides a piece of evidence for male-female wage differentials which could be explained through the difference in a human capital variable or through differences in occupational distributions. 
Table 5: Distribution of the sample across numerical variables (For a sample of males)

\begin{tabular}{lllllll}
\hline Variable & \multicolumn{3}{c}{ Arithmetic Mean } & \multicolumn{3}{c}{ Standard Deviation } \\
\cline { 2 - 7 } & $\mathbf{1 9 9 7 - 9 8}$ & $\mathbf{2 0 0 6 - 0 7}$ & $\mathbf{2 0 1 7 - 1 8}$ & $\mathbf{1 9 9 7 - 9 8}$ & $\mathbf{2 0 0 6 - 0 7}$ & $\mathbf{2 0 1 7 - 1 8}$ \\
\hline Monthly wage (Rs.) & 3335.4 & 6065.9 & 18708.3 & 2256.6 & 4853.7 & 12338.1 \\
Schooling (years) & 6.4 & 6.8 & 6.9 & 4.4 & 4.4 & 4.4 \\
Experience (years) & 33.6 & 32.9 & 33.5 & 11.6 & 11.8 & 11.8 \\
Working Hours & 48.9 & 50.8 & 49.9 & 10.6 & 11.8 & 11.4 \\
\hline
\end{tabular}

Source: Labour Force Survey, 1997-98, 2006-07, 2017-18

Table 6: Distribution of the sample across numerical variables (For a sample of females)

\begin{tabular}{lllllll}
\hline Variable & \multicolumn{3}{c}{ Arithmetic Mean } & \multicolumn{3}{c}{ Standard Deviation } \\
\cline { 2 - 7 } & $\mathbf{1 9 9 7 - 9 8}$ & $\mathbf{2 0 0 6 - 0 7}$ & $\mathbf{2 0 1 7 - 1 8}$ & $\mathbf{1 9 9 7 - 9 8}$ & $\mathbf{2 0 0 6 - 0 7}$ & $\mathbf{2 0 1 7 - 1 8}$ \\
\hline Monthly wage (Rs.) & 2665.0 & 4201.6 & 12877.5 & 2265.5 & 4807.9 & 13936.77 \\
Schooling (years) & 7.2 & 6.9 & 7.12 & 5.1 & 5.2 & 5.59 \\
Experience (years) & 31.8 & 31.5 & 32.69 & 11.4 & 11.3 & 11.19 \\
Working Hours & 39.9 & 40.5 & 38.74 & 11.1 & 11.5 & 10.32 \\
\hline
\end{tabular}

Source: Labour Force Survey, 1997-98, 2006-07, 2017-18

Figure 1 illustrates the average earning of males and females for three time periods, 1997-98, 2006-07, and 2017-18. However due to purchasing power parity difference, these three time periods are not comparable, but we can see that the average earning of the female is less than that of a male in all three years and difference exists in earnings for both genders due to differences in characteristics and due to discrimination.

Figure 2 is showing the percentage of males and females who acquired technical training, where we can see that share of females in the total sample has increased from 10.2 percent to 14.5 percent and then 16.8 percent but the male's share has decreased with time as in 1997-98 it was 89.8 percent then decreased to 85.5 percent in 2006-07 and then 83.2 percent in 2017-18.

If we see the percentage share of males and females in occupations with different skill levels, as shown in Figure 3, females' share has increased in skill level 1 occupation which is the lowest skill occupations, and males' share has decreased with time in skill level 1 occupation. While females' share in skill level 4 occupations which are the highest skill level occupations, has improved from 16 percent in 1997-98 to 30 percent in 2017-18.

Female's percentage share in the public sector has improved in as well as in private sector from 1997-98 to 2017-18. It can be seen in Figure 4 where males' share is decreased in both public and private sectors.

This section has focused on data and variables analysis, for both genders separately and we can see that on average females are less in almost every category. The average income of females is less than males in all three time periods, 199798, 2006-07, and 2017-18. However, their percentage share has increased over time but is less as compared to males. 
The Gender Wage Gap in Pakistan: Extent, Trends, and Explanations

igure 1: Average earning of male and female

20000

Figure 2: Percentage of males and females acquired technical training

100.0

\$ Male $\mathrm{g}$ Female

Figure 3: Percentage of males and females in occupations with skills levels

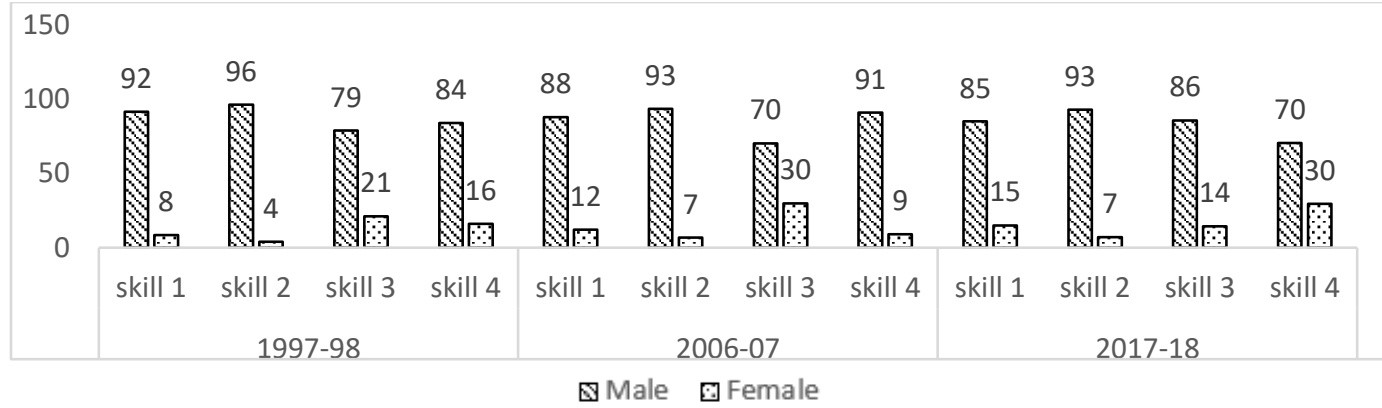

Figure 4: Percentage of males and females in public and private sector

$\underbrace{100}_{20}$

\$ Male 0 Female 


\subsection{Methodology}

According to the human capital approach by (Mincer, 1958, 1974; Becker, 1962), the gross annual wages of an individual can be related to past investments, where earnings are as the sum of wages which are received without investing in human capital and wage from past investment on human capital. This concept is modified as if humann capital investment cost is estimated through education and on-job-training then the equatin is:

$W=W_{0}+r_{1} S C H+r_{2} E X P+r_{3} E X P^{2}+u$

Where ' $r_{1}$ ' is the rate of return to schooling $(S C H)$, ' $r_{2}$ ' and ' $r_{3}$ ' determines the rate of return to experience $(E X P)$, and the negative value of ' $\mathrm{r}_{3}$ ' shows the concavity of earning function for the experience $\left(E X P^{2}\right)$. Schooling and then onjob-training are considered human capital investments where the assumption is that investment in job training decline linearly over time. The experience square term is used to capture the non-linearity of the model due to experience. Various studies used this framework to check the impact of education and experience which are two major human capital sources, have a positive and significant effect on individual earnings (Becker, 1962; Mincer, 1974).

Mincer's human capital wage function and its different forms are used to check the effect of education and other variables on the wages of male and female workers. Shabbir (1994) have used Mincerian earning function for Pakistan and used dummy variables for occupations, provinces, and location of residence whether rural or urban.

Mincer's human capital wage function and its different forms are used to check the effect of education and other variables on the wages of male and female workers. The general form of earning function is:

$W_{i}=f\left(X_{i}\right)+u_{i}$

Where $W_{i}$ is the natural $\log$ of monthly wages of individual $i, X_{i}$ is a vector of personal characteristics of individual $i$, and $u_{i}$ is the random disturbance term. The raw mathematical equation is given below;

$W=f(D E M, S E, J S)$

From equation (2) is:

$W_{i}=\theta X_{i}+u_{i}$

Where, $\theta$ represents the vector of parameters. The vector $X$ contain variables related to $D E M, S E$, and $J S$, respectively. For separating the factors of 
wage differential i.e. difference in individual's characteristics and discrimination or difference in unobserved variables.

Based on the methodology of Oaxaca (1973) and Blinder (1973), the wage equation of males and females can be decomposed into two parts: endowment difference or differences in individual characteristics and differences in estimated coefficients. This can be obtained through fitted regression of equation through OLS estimation, it yields the following equations:

$$
\begin{aligned}
& \ln W_{i}^{M}=\alpha^{M}+\sum_{j, i=1}^{k, n} \beta_{j}^{M} X_{i j}^{M} \\
& \ln W_{i}^{F}=\alpha^{F}+\sum_{j, i=1}^{k, n} \beta_{j}^{F} X_{i j}^{F}
\end{aligned}
$$

Where, $i=1,2, \ldots, N$ for individuals and $j=1,2, \ldots, K$ for individuals' characteristics. The difference between equations (5) and (6) at mean values can be expressed as:$$
\ln \bar{W}_{i}^{M}-\ln \bar{W}_{i}^{F}=\left(\alpha^{M}-\alpha^{F}\right)+\sum_{j, i=1}^{k, n} \beta_{j}^{M}\left(\bar{X}_{i j}^{M}-\bar{X}_{i j}^{F}\right)+\sum_{j, i=1}^{k, n} \bar{X}_{i j}^{F}\left(\beta_{j}^{M}-\beta_{j}^{F}\right)
$$

A simplified version of equation (7) is as follows:

$\ln \bar{W}^{M}-\ln \bar{W}^{F}=\left(\alpha^{M}-\alpha^{F}\right)+\beta^{M}\left(\bar{X}^{M}-\bar{X}^{F}\right)+\bar{X}^{F}\left(\beta^{M}-\beta^{F}\right)$

The first and third terms on the right side of equation (8) describe the discrimination effect which cannot be explained by the differences in observed characteristics, the second term describes the average endowment effect or difference in observed characteristics of two groups which are male and female in our study.

Another method of decomposition is introduced by Neuman and Oaxaca (2004) which is based on a selectivity-corrected wage equation and will be employed in this study. The sample of employed individuals is not a random selection of the population so, the male and female wage equations adopted twostep selectivity correction (Heckman, 1979). The selectivity-corrected wage equation is a transformed form of equation (8) and is as follows:

$$
\begin{aligned}
& \ln \bar{W}^{M}-\ln \bar{W}^{F}=\left(\alpha^{M}-\alpha^{F}\right)+\beta^{M}\left(\bar{X}^{M}-\bar{X}^{F}\right)+\bar{X}^{F}\left(\beta^{M}-\beta^{F}\right)+\left(\theta^{M} \lambda^{M}-\right. \\
& \left.\theta^{F} \lambda^{M}\right)
\end{aligned}
$$


Where the term $\left(\theta^{M} \lambda^{M}-\theta^{F} \lambda^{M}\right)$ denotes the sample selectivity bias effects. This equation is introduced by Neuman and Oaxaca (2004) which is used to control for biases in estimation. Where $\theta$ is a product of error's standard deviation $\sigma_{\mu}$ and the correlation between selection equation error and wage equation error which is $\rho$ and then $\lambda$ is the estimate of the mean of Inverse Mills Ratio (IMR).

\section{Results}

This section examines the determinants of wages to evaluate the females' wages as compared to that of males using the decomposition technique introduced by Oaxaca (1973) and Blinder (1973). This approach on which our hypotheses (one, demographic, socioeconomic, and job-specific factors significantly affect gender wage differential; second, gender wage differential have increased over time in Pakistan) are tested has less application in Pakistan.

\subsection{Exploratory Analysis}

Before moving towards empirical analysis, we would like to perform exploratory analysis on our data. First, five Quantiles of income are made for all three years, and then it is explored that how much males and females fall in each category of different categorical variables. In Table 7, marital status is divided into four categories, not married, married, widowed, and divorced, and we can see that in 1997-98 21.6 percent of males and 29.3 percent of females who were married were on lower levels of income compared to 17.1 percent of males and 28.5 percent of a female who was not married /widow/divorced. Likewise, 33.6 percent of males and 18.5 percent of females were married and were getting higher 40 percent of income level compared to 6.9 percent of males and 9.1 percent of females who were not married/widowed /divorced.

For the year 2006-08, 19.3 percent of males and 30 percent of females were married and getting bottom 40 percent of income levels as compared to 10.7 percent of males and 32.2 percent of females who were not married. Same as 29.5 percent of males and 16.4 percent of females were married and getting higher income to compare to 6.1 percent of males and 9.3 percent of females were not married. For 2017-18, 21.8 percent of males and 35.6 percent of females were having bottom 40 percent of income levels as compared to 17.1 percent of males and 28.1 percent of females who were not married/widowed/divorced. For higher 40 percent of income there were 32.8 percent married males and 18.3 percent married females, as compared to 6.4 percent of males and 9.6 percent of females who were not married or widowed or divorced. 
Moreover, the percentage distribution of males and females in occupations with different skill levels with 5 income groups is presented in Table 8, where we can see that in 1997-98, lower the skills occupations lower the income levels, there are 17.3 percent males and 27.7 percent females, and higher the skill level and higher the income, there are, 8.7 percent of males and 14.9 percent of females. Likewise, for the year 2006-07, higher skill level occupations and higher income levels, 6.7 percent male and 6.4 percent female which are almost the same, and with lower skills occupation and lower-income levels, there are 16.2 percent males and 15.2 percent females. For the year 2017-18, female's share in high-income and high skills jobs has increased from 6.4 percent in 2006-07 to 21.0 percent, and male's share has also increased but slightly. From 1997-98 to 2017-18 female's share has decreased, in the lower level of income and lower skills occupations, from 27.7 percent to 17.4 percent.

Table 9 shows the percentage distribution of males and females in the public and private sector with five income levels. In the public sector, for lower-income levels male percentage has decreased from 10.2 percent in $1997-98$ to 3.5 percent in 2017-18 and for higher income levels percentage of males has decreased to 3 percent. The percentage of females in the public sector and on the lower level of income has also decreased from 10.2 percent in 1997-98 to 3.5 percent in 2017-18. For the private sector, females' percentage share has drastically increased from 46.5 percent in 1997-98, 53.5 percent in 2006-07 to 60.2 percent in 2017-18 at a lower level of income but at a higher level of income it has been slightly increased, 5.7 percent in 1997-98 to 6.0 percent in 2017-18. In the private sector males' share has also increased but slightly for both high-income levels and low-income levels. 
Yasmin, Jamil and Iqbal

Table 7: Percentage distribution of both genders according to marital status and quantiles of income

\begin{tabular}{|c|c|c|c|c|c|c|c|c|c|c|c|c|c|c|c|c|c|c|c|c|c|c|c|c|c|c|c|c|}
\hline & \multicolumn{9}{|c|}{ 1997-98 } & \multicolumn{10}{|c|}{ 2006-07 } & \multicolumn{9}{|c|}{ 2017-18 } \\
\hline & 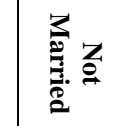 & & 党 & & 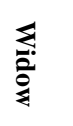 & & 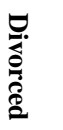 & & $\overrightarrow{0}$ & . & $\stackrel{z}{g}$ & & .3. & & : & & 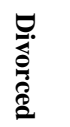 & & $\overrightarrow{0}$ & 蛋 & $\stackrel{z}{a}$ & & .3. & & 通 & & 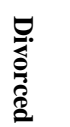 & $\overrightarrow{\vec{D}}$ \\
\hline & M F & $\mathbf{M}$ & $\mathbf{F}$ & M & $\mathbf{F}$ & M & $\mathbf{F}$ & $\mathbf{M}$ & $\mathbf{F}$ & M & $\mathbf{F}$ & M & $\mathbf{F}$ & $\mathbf{M}$ & $\mathbf{F}$ & $\mathbf{M}$ & $\mathbf{F}$ & $\mathbf{M}$ & $\mathbf{F}$ & $\mathbf{M}$ & $\mathbf{F}$ & $\mathbf{M}$ & $\mathbf{F}$ & $\mathbf{M}$ & $\mathbf{F}$ & $\mathbf{M}$ & $\mathbf{F}$ & $\mathbf{F}$ \\
\hline & 9.117 .6 & 9.4 & 22.6 & 0.3 & 4.3 & 0 & 0 & 18.9 & 45.0 & 9.4 & 22.5 & 57.2 & 24.2 & 0.2 & 3.0 & 0.0 & 0.5 & 16.8 & 50.2 & 9.2 & 19.5 & 9.4 & 31.5 & 0.2 & 4.4 & 1 & .6 & 18.956. \\
\hline & 7.14 .6 & 12. & & 0.4 & 1.4 & 0.1 & 0. & 19.8 & 12.8 & 10.7 & 5.2 & 12.1 & 15.8 & 0.2 & 0.8 & 0.1 & 0. & 23.1 & & 7.3 & 2.9 & 12.4 & 4.1 & 0.2 & 0.5 & 0.1 & 0.2 & 20.07 .7 \\
\hline & $\begin{array}{ll}5.8 & 5.7\end{array}$ & 14. & & 0.2 & 1. & & & 20.8 & 14 & 7.7 & 4.8 & 1 & 56.6 & 0 & & & & & & 6.5 & 3 . & & & 0 & & & & \\
\hline & 3.93 .0 & & & 0 & & & & & 13 & 2.7 & 2.4 & & & 0 & & & & & & 3.8 & 4.2 & & 5 & 0 & & & & 19.6 \\
\hline $5^{\text {th }}$ & 2.64 .1 & 17. & & 0.2 & 0.7 & 0.0 & 0.0 & 20.5 & 14.4 & 3.0 & 5.1 & 17.2 & 210.2 & 0.2 & 0.8 & 0.0 & 0.3 & 20.4 & 16.4 & 2.2 & 4.5 & 17.2 & 12.6 & 0.2 & 0.4 & 0.0 & 0.2 & 19.617 .7 \\
\hline Tota & \begin{tabular}{l|l}
11 & 28.535 .0
\end{tabular} & 70. & 055.4 & 1.3 & 8.8 & 0.2 & 0.8 & 100 & 100 & 33.5 & 40.0 & 65.3 & 353.0 & 1.1 & 5.7 & 0.1 & 1.3 & 100 & 100 & 29.1 & 34.1 & 69.6 & 58.7 & 1.0 & 5.9 & 0.3 & 1.3 & $100 \quad 100$ \\
\hline
\end{tabular}

Table 8: Percentage distribution of both genders according to occupations by skills and quantiles of income

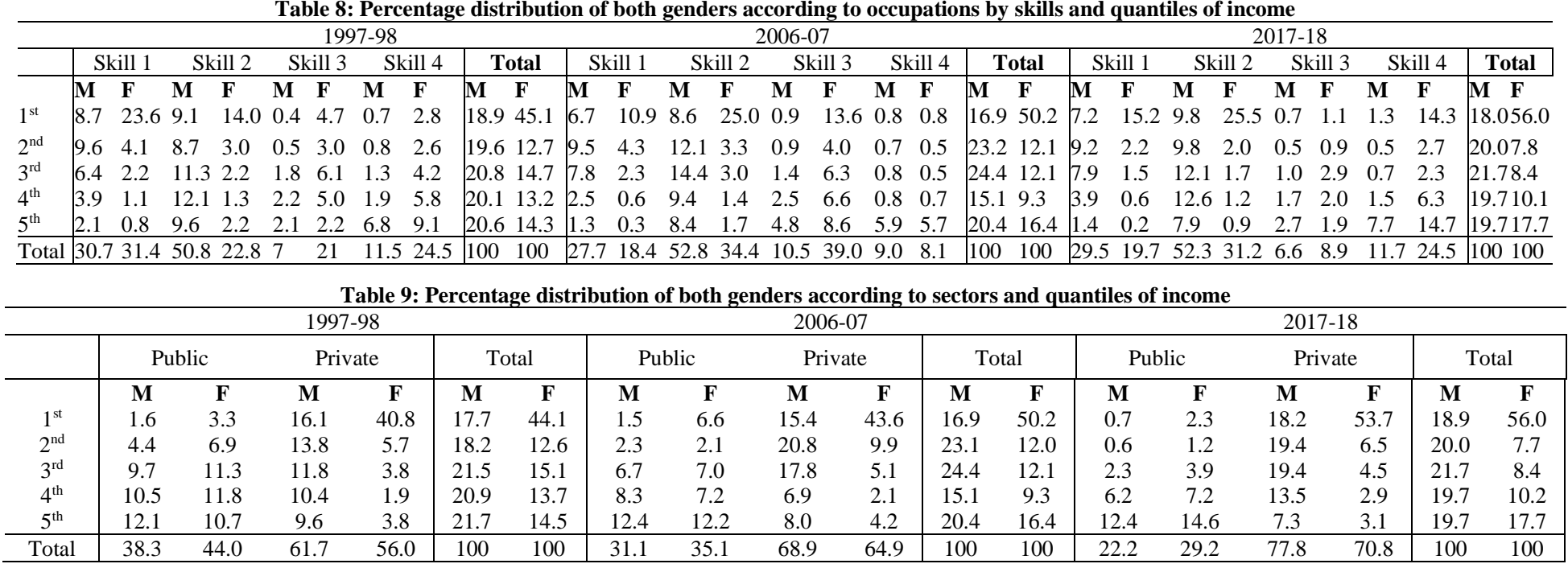




\subsection{Empirical Analysis}

The basic empirical analysis in this section describes the differences between specific factors included in male and female earning equations.

The coefficients of all explanatory variables by estimating equations 5 and 6 are shown in Table 10 where the human capital variables are highly significant for both genders, males and females. All other explanatory variables are highly significant for males but some of them are insignificant for females. On average, years of schooling is associated with about 3 percent, 4 percent, and 2 percent increase in wages for males and 6 percent, 6 percent, and 5 percent increase in wages for females for 1997-98, 2006-07, and 2017-18 respectively showing a slightly better rate of return for females as compared to males. However, the rate of return to each year of experience is more for females than males in the year 199798, while the rate of return to experience is greater for males in 2006-07 and 201718. It is clear from the results that there is a positive relationship between experience and wages. ${ }^{9}$ The estimated coefficients for experience-square is negative and significant for both male and female, confirming the concavity of ageearning profile. The highly significant coefficients of schooling and experience prove the applicability of the human capital model for both males and females in Pakistan.

Technical training is found to be significant for males but insignificant for females. ${ }^{10}$. Internal migration is also a significant factor to increase male's wages but for females, it is negative and insignificant for 1997-98 and positive and significant for other two years.

The coefficient estimates for married individuals show the same patterns which are consistent with human capital theory. The marital status of an individual plays an important role in determining his/her wages. We found that married males are earning more than unmarried males, while the coefficient for a married female is insignificant for all three years. Langdon and Klomegah (2013) showed that except marital status all other explanatory variables used in the study are significant to wages. Furthermore, more working hours are associated with higher levels of earnings for an individual by less than 1 percent for males and around 1 percent for females, for females more working hours increases wages more than male. ${ }^{11}$

\footnotetext{
${ }^{9}$ This is also supported by Biltagy (2018)

${ }^{10}$ See Nasir (2002)

${ }^{11}$ See Biltagy (2018)
} 
Table 10: Regression results of wage equation (separately for males and females) ${ }^{12}$

\begin{tabular}{|c|c|c|c|c|c|c|}
\hline \multirow{2}{*}{ Variables } & \multicolumn{2}{|c|}{$1997-98$} & \multicolumn{2}{|c|}{ 2006-07 } & \multicolumn{2}{|c|}{$2017-18$} \\
\hline & Male & Female & Male & Female & Male & Female \\
\hline $\mathrm{SCH}$ & $.0318 * * *$ & $.0599 * * *$ & $.0396 * * *$ & $.0608 * * *$ & $.0264 * * *$ & $.0419 * * *$ \\
\hline EXP & $.0418 * * *$ & $.0522 * * *$ & $.0474 * * *$ & $.0358 * * *$ & $.0285 * * *$ & $.0308 * * *$ \\
\hline $\mathrm{EXP}^{2}$ & $-.00045^{* * *}$ & $-.0006^{* * * *}$ & $-.0005^{* * * *}$ & $-.0004 * * *$ & $-.0002 * * *$ & $-.0003 * * *$ \\
\hline TRA & $.0815^{* * *}$ & -.0964 & $.1027 * * *$ & -.0038 & $.0178 * *$ & $.1094 * * *$ \\
\hline MIG & $.1037 * * *$ & -.0320 & $.1016^{* * * *}$ & $.0934 * * *$ & $.0629 * * *$ & $.1303^{* * * *}$ \\
\hline MAR & $.0576^{* * * *}$ & .0456 & $.0384 * * *$ & .0107 & $.0505^{* * *} *$ & .0043 \\
\hline WHR & $.0042 * * *$ & $.0160 * * *$ & $.0034 * * *$ & $.0159 * * *$ & $.0047 * * *$ & $.0190^{* * * *}$ \\
\hline PUB & $.0782 * * *$ & $.4169 * * *$ & $.2839 * * *$ & $.6320 * * *$ & $.1531^{* * * *}$ & $1.125^{* * * *}$ \\
\hline SKL_2 & $.1055^{* * * *}$ & $.1433^{* *}$ & $.1118^{* * * *}$ & -.0049 & $.3276^{* * * *}$ & $-.4766^{* * * *}$ \\
\hline SKL_3 & $.1425^{* * * *}$ & -.0987 & $.1156^{* * * *}$ & $-.1192^{* *}$ & $.3249 * * *$ & -.0341 \\
\hline SKL_4 & $.3653 * * *$ & .0769 & $.4458 * * *$ & $.5549 * * *$ & $.4524 * * *$ & $.1868 * * *$ \\
\hline PUN & $-.0774 * * *$ & $-.1599 * * *$ & $.0203 * *$ & $-.1315^{* * * *}$ & $.1116^{* * * *}$ & $-.1815^{* * * *}$ \\
\hline KP & $-.1257 * * *$ & -.0606 & $-.0598 * * *$ & -.0834 & $.2058 * * *$ & $-.0768^{*}$ \\
\hline BAL & $.0502 * * *$ & .0752 & $.0361 * * *$ & $.1805^{* *}$ & $.2608 * * *$ & $-.1173 *$ \\
\hline $\begin{array}{l}\text { WLO } \\
\text { Cons. }\end{array}$ & $\begin{array}{l}.1256^{* * * *} \\
6.466\end{array}$ & $\begin{array}{l}.0526 \\
5.459\end{array}$ & $\begin{array}{l}.0704 * * * \\
6.826\end{array}$ & $\begin{array}{l}.1409 * * * \\
5.939\end{array}$ & $\begin{array}{l}.0584 * * * \\
8.3584\end{array}$ & $\begin{array}{l}.1656^{*} \\
6.9182 \\
\end{array}$ \\
\hline $\mathrm{N}$ & 9,355 & 787 & 20,708 & 2,609 & 26,166 & 3,860 \\
\hline Prob $>F$ & 0.0000 & 0.0000 & 0.0000 & 0.0000 & 0.0000 & 0.0000 \\
\hline $\begin{array}{l}\text { R-squared } \\
\text { Root MSE }\end{array}$ & $\begin{array}{l}0.3279 \\
.46602\end{array}$ & $\begin{array}{l}0.4996 \\
.5353\end{array}$ & $\begin{array}{l}0.3774 \\
.5202\end{array}$ & $\begin{array}{l}0.5225 \\
.62686\end{array}$ & $\begin{array}{l}0.3810 \\
.4838\end{array}$ & $\begin{array}{l}0.5767 \\
.59052\end{array}$ \\
\hline
\end{tabular}

Source: Authors own calculation, where $* * *, * * *$ indicates significance at $1 \%, 5 \%$ and $10 \%$ level of significance, respectively.

The employment sector is considered one of the main determinants of the wages of an individual. The public sector is a categorical variable and the private sector is taken as the reference category, and we can see that there is a significant increase in the coefficient of public sector employment for both genders, from $1997-98$ to $2017-18$.

Skills levels are included to check what will be the effect of skill levels on earning for male and female, where skill level 1 is taken as the reference category and results shows that as the skill level increase, there is an increase in male' wages for all three years. While, for females from skill level 2 to skill level 3 wages decreased as compared to skill 1, and in 2017-18, as the skill level increases, wages decrease as compared to skill level 1. In middle-skill occupations, workers in female-dominated occupations are earning 66 percent of what the male workers earn in male-dominated occupations (Aly, 2017).

To capture the effects of labor market conditions and geographic location and other possible effects, we introduced dummy variables for the 4 provinces

\footnotetext{
${ }^{12}$ For overall regression results see Appendix A
} 
where Sindh is taken as the reference category. In Punjab and KP, females are earning less than females in Sindh, but in Baluchistan, females are earning more than females in Sindh. Males of Punjab and KP were earning less in 1997-98 compared to males in Sindh but in 2017-18 they are earning more than males of Sindh. Work location is a categorical variable, whether an individual is working in an urban area or rural area, and the coefficient of work location shows that as compared to people working in rural areas, people working in urban areas earn more.

We have used the Heckman two-step procedure and incorporated lambda into the earnings function for the correction of selectivity biases. In Pakistan, the sample selectivity problem does not significantly affect the estimated value. ${ }^{13} \mathrm{In}$ our case, the selectivity problem is not affecting the estimated values as their probability is not significant and there is no sample selectivity problem in the year 1997-98 and 2006-07 but for the year 2017-18 selectivity problem exists its probability value is significant at 5 percent of the significance level.

\subsection{Oaxaca- Blinder and Neuman- Oaxaca wage Decomposition Results}

The unexplained part of the wage gap is usually treated in the literature as an estimate of wage discrimination. However, as is well known, the discrimination effects can be overstated if some important explanatory variables are missing. On the contrary, the unexplained part will also understate discrimination if some of the explanatory variables have themselves been influenced by discrimination (Blau and Kahn, 2017)

Percentage male-female wage differential for the entire sample is listed in Table 12, where we can see that there is a 39.9 percent wage gap between male and female in 1997-98, 79.9 percent in 2006-07, and 87.7 percent in 2017-18. ${ }^{14}$ The detailed male-female differential is presented in Table 11 which is estimated through equation 9, where it is shown that except for experience males do not have an advantage in schooling, training, or migration, as confirmed by the negative coefficients of these variables.

Moreover, in the public sector females have an advantage over males in terms of wages and this might be due to the reason that generally females go for high-paid jobs in the public sector. and same is the case with higher skills where females have an advantage, on skill level 3 and skill level 4 coefficient is negative

\footnotetext{
${ }^{13}$ See Ashraf et al. (1993)

${ }^{14}$ A $\log$ earning differential of 0.6299 , reported in Table 12 is equivalent to 87.7 percent, using the formula $\left(e^{\alpha}-1\right)^{*} 100$ where $\alpha=0.6299$
} 
and significant. In province KP, females are earning more but in Punjab and Baluchistan females have a disadvantage in wages.

Table 11: Results of wage decomposition analysis

\begin{tabular}{|c|c|c|c|c|c|c|}
\hline \multirow{2}{*}{$\begin{array}{l}\text { Variables } \\
\mathrm{SCH}\end{array}$} & \multicolumn{2}{|c|}{$1997-98$} & \multicolumn{2}{|c|}{ 2006-07 } & \multicolumn{2}{|c|}{ 2017-18 } \\
\hline & $-.0248 * * *$ & $(-3.90)$ & -.0068 & $(-1.52)$ & $-.0062 * *$ & $(-2.56)$ \\
\hline EXP & $.0757 * * *$ & $(4.10)$ & $.0621 * * *$ & $(5.43)$ & $.0305 * * *$ & $(4.31)$ \\
\hline $\mathrm{EXP}^{2}$ & $-.0563 * * *$ & $(-3.85)$ & $-.0482 * * *$ & $(-5.47)$ & $-.0252 * * *$ & $(-4.72)$ \\
\hline TRA & $-.0014^{*}$ & $(-1.67)$ & $-.0006^{* *}$ & $(-1.80)$ & $-.0043 * * *$ & $(-5.84)$ \\
\hline MIG & $-.0035^{* *}$ & $(-2.33)$ & $-.0045 * * *$ & $(-4.83)$ & $-.0052 * * *$ & $(-6.52)$ \\
\hline MAR & $.0038 * *$ & $(2.43)$ & $.0009 * *$ & (1.87) & .0002 & $(0.93)$ \\
\hline WHR & $.0516^{* * *}$ & $(9.85)$ & $.0566^{* * * *}$ & (15.18) & $.0919 * * *$ & (25.05) \\
\hline PUB & $-.0082 * * *$ & $(-3.75)$ & .00005 & $(0.02)$ & $-.0122 * * *$ & $(-3.20)$ \\
\hline SKL_2 & $.0308 * * *$ & $(8.46)$ & $.0211 * * *$ & (10.20) & $.0093^{* * *} *$ & $(4.52)$ \\
\hline SKL_3 & $-.0225 * * *$ & $(-5.96)$ & $-.0263 * * *$ & $(-7.59)$ & $-.0016^{* *}$ & $(-2.03)$ \\
\hline SKL_4 & $-.0498 * * *$ & $(-7.62)$ & $.0084 * * *$ & $(3.43)$ & $-.0634 * * *$ & $(-17.0)$ \\
\hline PUN & $.0192 * * *$ & $(6.39)$ & .0008 & $(-0.38)$ & $-.0149 * * *$ & $(-8.09)$ \\
\hline $\mathrm{KP}$ & $-.0068 * * *$ & $(-4.14)$ & $-.0025^{* * *} *$ & $(-3.71)$ & $.0143^{* * *} *$ & (11.32) \\
\hline BAL & $.0037 * * *$ & (3.12) & $.0027 * * *$ & $(2.76)$ & $.0137 * * *$ & (13.23) \\
\hline WLO & $.0099 * * *$ & $(4.26)$ & $.0101 * * *$ & (7.98) & $.0117 * * *$ & $(10.20)$ \\
\hline Total Explained & .0211 & $(1.33)$ & .0722 & $(6.79)$ & .0384 & (3.99) \\
\hline Total Unexplained & .3152 & (14.38) & .5152 & $(35.49)$ & .5915 & (33.38) \\
\hline Total Gap & .3363 & $(12.30)$ & .5874 & $(32.11)$ & 6299 & $(31.39)$ \\
\hline
\end{tabular}

Source: Authors own calculation, $\mathrm{z}$-values are in parenthesis, where $* * *, * *, *$ indicates significance at $1 \%, 5 \%$ and $10 \%$ level of significance, respectively.

If we see these differentials in percentage form, then 93.72 percent, 87.71 percent, and 93.76 percent of monthly wage differential for the year 1997-98, 200607, and 2017-18 respectively, is unexplained by our independent or explanatory variables and thus attributed to discrimination presented in Table 12, where 6.28 percent, 12.29 percent and 6.24 percent of wage differential is due to the difference in characteristics.

Table 12: Wage decomposition results (in percentage)

\begin{tabular}{|c|c|c|c|c|c|c|}
\hline & \multicolumn{2}{|c|}{$1997-98$} & \multicolumn{2}{|c|}{$2006-07$} & \multicolumn{2}{|c|}{ 2017-18 } \\
\hline $\begin{array}{l}\text { Due to endowments } \\
\text { (explained) }\end{array}$ & .0211 & $6.28 \%$ & .0722 & $12.29 \%$ & .0384 & $6.09 \%$ \\
\hline $\begin{array}{l}\text { Due to returns to explanatory } \\
\text { variables (unexplained) }\end{array}$ & -.6921 & $-205.78 \%$ & -.3707 & $-63.11 \%$ & -.2154 & $-34.20 \%$ \\
\hline Intercept differential & 1.0076 & $299.59 \%$ & .8859 & $150.82 \%$ & .8069 & $128.12 \%$ \\
\hline $\begin{array}{l}\text { Total differential due to } \\
\text { discrimination }\end{array}$ & .3152 & $93.72 \%$ & .5152 & $87.71 \%$ & .5915 & $93.92 \%$ \\
\hline $\begin{array}{l}\text { Overall wage differential } \\
\text { (difference in log wages) }\end{array}$ & .3363 & $100 \%$ & .5874 & $100 \%$ & 6299 & $100 \%$ \\
\hline
\end{tabular}

Source: Authors own calculations

It is estimated that $\ln \bar{W}_{M}-\ln \bar{W}_{F}=.3363$, that is a 33.6 percent wage gap in 1997-98. Also, $\left(\bar{X}_{M}-\bar{X}_{F}\right) \hat{\beta}_{M}=.0211$, the endowment or characteristics effect is 2.11 percent, and the discrimination effect is given by $\left(\hat{\beta}_{M}-\hat{\beta}_{F}\right) \bar{X}_{F}=.3152$ is 31.52 percent. The discrimination effect is the difference in coefficients plus the difference in constant terms. 
The 2006-07 estimates show that the wage gap is approximately 59 percent where $\ln \bar{W}_{M}-\ln \bar{W}_{F}=.5874$ and endowment effect is 7.2 percent because $\left(\bar{X}_{M}-\right.$ $\left.\bar{X}_{F}\right) \hat{\beta}_{M}=.0722$ and discrimination effect is 51.5 percent where $\left(\hat{\beta}_{M}-\hat{\beta}_{F}\right) \bar{X}_{F}$ $=.5152$. In 2017-18 wage gap increases to 62.9 percent where $\ln \bar{W}_{M}-\ln \bar{W}_{F}=$ .6299 and endowment effect is 3.8 percent where $\left(\bar{X}_{M}-\bar{X}_{F}\right) \hat{\beta}_{M}=.0384$ and 59.15 percent is discrimination effect where $\left(\hat{\beta}_{M}-\hat{\beta}_{F}\right) \bar{X}_{F}=.5915$.

Where if we see these differences in Pakistani rupee Table 13, then the mean value of real monthly wages is 2822.5 rupees for males and 2016.4 rupees for females in 1997-98 (the wage gap is 806.1 rupees), in this year without discrimination against females, their monthly wages should be 2771.9 rupees, this means females were earning 755.5 rupees less in their monthly earnings due to the factors that cannot be explained, expressed as discrimination. By using labor force survey data 2006-07, a mean value of real monthly wages was 4834.6 Pakistani rupees for males and 2686.96 Pakistani rupees for females (the wage gap is 2147.6 rupees) and if there will be no discrimination, females tend to earn 4584.6 rupees and it means they are earning 1897.6 rupees less than what they should have earned, this is gender-based discrimination.

Table 13: Wage decomposition results (in Pakistani Rupee)

\begin{tabular}{|c|c|c|c|c|c|c|}
\hline \multirow[t]{2}{*}{ Wage Decomposition components } & \multicolumn{3}{|c|}{ Males } & \multicolumn{3}{|c|}{ Females } \\
\hline & $1997-98$ & 2006-07 & 2017-18 & $\begin{array}{l}1997-98 \\
\end{array}$ & 2006-07 & 2017-18 \\
\hline Mean value of real monthly wages & 2822.5 & 4834.6 & 15574.3 & 2016.4 & 2686.97 & 8326.2 \\
\hline Overall wage gap & & & & 806.1 & 2147.6 & 7248.1 \\
\hline Wage without discrimination effect & & & & 2771.9 & 4584.6 & 14610.3 \\
\hline Discrimination effect & & & & 755.5 & 1897.6 & 6806.3 \\
\hline Endowments effect & & & & 50.7 & 250.1 & 441.8 \\
\hline
\end{tabular}

Source: Authors own calculation, all values are in Pakistani Rupee.

So, in 2017-18, we can see that out of total differential, the endowment effect has decreased from 6.24 percent to 6.09 percent, but total differential due to discrimination has increased slightly from 93.76 percent to 93.92 percent. Table 13 shows the difference in Pakistani Rupees, where the same results are presented as selectivity effect has increased wage differential due to endowments from 964.1 to 441.8 Pakistani rupees, and wage difference due to discrimination has increased from 6284.1 rupees to 6806.3 rupees. The overall difference (in log form) for the year 2017-18 has adjusted to 0.6299 from 0.6262 , which means due to selectivity there is a slight increase in the male-female wage differential.

For the year 2017-18 mean value of real monthly wages was 15574.3 rupees for males and 8326.2 rupees for females (wage gap is 7248.1 percent) and if there is no discrimination, females would earn 14610.3 rupees and with the 
discrimination, they were earning 6284.1 rupees less ${ }^{15}$. These results show that the gender wage gap has drastically increased from 1997-98 to 2017-18, Major portion of this differential is unexplained or due to discrimination, very little wage gap is due to endowment or characteristic difference.

\section{Concluding Remarks}

Gender differences in productivity of labor and wages are mainly due to the differences in economic activities of males and females with gender differences in returns to work and human capital and job characteristics. About job characteristics, male's and female's jobs are very different, across sectors and occupations. Generally, females tend to be concentrated in low productivity jobs, and they usually prefer the job which offers flexible working hours and other arrangements, so they can manage work with other responsibilities and these jobs are often parttime or informal jobs.

This study has focused on explaining the wage gap between males and females in Pakistan by determining the wage differential due to differences in characteristics between males and females and other differences which are unidentified and often categorized as discrimination against females. This study uses LFS 1997-98, 2006-07, and 2017-18 to estimate the size of the gender wage gap in Pakistan. The data and results show that real monthly wages are more for males than females and the wage gap increases from 39.9 percent in 1997-98 to 79.9 percent in 2006-07 and 87.7 percent in 2017-18, and this shows the worsening conditions of the Pakistani labor market.

The Oaxaca-Blinder decomposition of the wage gap between males and females demonstrates that most of the wage gap is due to discrimination against females in the labor market and very little due to low levels of human capital characteristics, for example, education levels and experience. A major part of the gender wage gap is mysterious (Hirsch, 2016), however, it is somehow explained by discrimination which is imposed by the employer side where male and female wage differential can be called "monopolistic" wage discrimination and this term shows that employers make decisions by their own without preferences.

As females are not behind the males in their abilities and skill levels, so main thing is to educate males who decide females' future, especially in the case of Pakistan where father and husband play a key role in decision making for females. As data showed that female has on average one year more of education than males, so female should be given equal access to education because this will cause a

\footnotetext{
${ }^{15}$ Results of the data without trimming are shown in Appendix B, Appendix C.
} 
vicious circle, as if the current generation of females are not treated equally as males in the attainment of educational opportunities then it will lead to lack of empowerment and this discrimination will have a major effect on coming generation (Qureshi, 2012). To decrease the gender wage gap, standards of labor should be promoted, especially in the private sector, because in our study, results show that in the public sector female have an advantage over the male in wage perspective. So, there is a need for legislation of anti-discrimination, such as equal pay acts and regulations which prevent discrimination in rank, wage, and entrance criteria for labor markets.

This study used the age for several years, but age can be disaggregated in different age groups to check the labor force participation of males and females across different age groups. Schooling is taken as completed levels of schooling, instead, future research may take schooling with different levels. Other than this, for females' labor force participation and wages, parents' and husband's education is an important factor, which can be included in the research, but this information is not given in LFS. 


\section{References}

Aly, Y. (2017). The gender wage gap: Causes, consequences, and remedies. In BSU Honors Program Theses and Projects, Bridgewater State University, Massachusetts, United State. Available at: https://vc.bridgew.edu/honors_proj/243

Ashraf, J., Ashraf, B., \& Ahmed, A. M. (1993). An analysis of the male-female earnings differential in Pakistan. The Pakistan Development Review, 32(4), 895-904.

Babcock, L., Laschever, S., Gelfand, M., \& Small, D. (2003). Nice girls don't ask. Harvard Business Review, 81(10), 14-14.

Becker, G. S. (1957). The Economics of Discrimination: An Economic View of Racial Discrimination(Second Edition). The University of Chicago: Chicago.

Becker, G. S. (1962). Investment in human capital: A theoretical analysis. Journal of Political Economy, 70(5), 9-49.

Becker, G. S. (1964). Human Capital: A Theoretical and Empirical Analysis, with Special Reference to Education (First Edition).NBER: Cambridge.

Bergmann, B. (1974). Occupational segregation, wages and profits when employers discriminate by race and sex. Eastern Economic Journal, 1(2), 103-110.

Biltagy, M. (2018). Gender wage disparities in Egypt: Evidence from ELMPS 2006 and 2012. The Quarterly Review of Economics and Finance, 73, 14-23.

Blinder, A. S. (1973). Wage discrimination: Reduced form and structural estimates. Journal of Human Resources, 47(4), 436-455.

Blau, F. D. (1996). Where are we in the economics of gender? The gender pay gap. NBER, 5664.

Blau, F. D., \& Kahn, L. M. (2017). The gender wage gap: Extent, trends, and explanations. Journal of Economic Literature, 55(3), 789-865.

Chakraborty, S. (2020). Gender wage differential in public and private sectors in India. The Indian Journal of Labour Economics, 63(3), 765-780.

Cotton, J. (1988). On the decomposition of wage differentials. The Review of Economics and Statistics, 70(2) 236-243. 
Corcoran, M., \& Duncan, G. J. (1979). Work history, labour force attachment, and earnings differences between the races and sexes. Journal of Human Resources, 14(1), 3-20.

De Ruijter, J. M., \& Huffman, M. L. (2003). Gender composition effects in the Netherlands: A multilevel analysis of occupational wage inequality. Social Science Research, 32(2), 312-334.

Denison, E. F. (1966). Measuring the contribution of education to economic growth. In The Economics of Education. Palgrave Macmillan: London.

Duraisamy, P. (2002). Changes in returns to education in India, 1983-94: By gender, age-cohort and location. Economics of Education Review, 21(6), 609622.

Farooq, M., \& Sulaiman, D. J. (2009). Gender earnings inequality and discrimination in the Pakistani labor market. Dialogue, 4(3), 1819-6462.

Geleta, K. M. (2021). A GLM approach to decomposing wage differential: Evidence from the PSID. Doctoral Dissertation, Northern Illinois University, United State.

Gilbert, N. (1994). Gender equality and social security. Society, 31(4), 27-33.

Hagiwara, T. A., Camingue, S., \& Zveglich, J. E. (2018). Gender pay gap: A macro perspective. ADB Economics Working Paper Series, 538.

Heckman, J. J. (1979). Sample selection bias as a specification error. Journal of the Econometric Society, 47(1), 153-161.

Hirsch, B. (2016). Gender: Does the extent of competition in labour markets explain why female workers are paid less than men?. IZA World of Labour, 310, 110

Hyder., \& Reilly. (2005). The public and private sector pay gap in Pakistan: A quantile regression analysis. The Pakistan Development Review,44(3), 271306.

IMF. (2013). International Monetary Fund Annual Report 2013: Promoting a More Secure and Stable Global Economy. Available at: https://www.imf.org/en/Publications/AREB/Issues/2016/12/31/International -Monetary-Fund-Annual-Report-2013-Promoting-a-More-Secure-and$\underline{\text { Stable-Global-40629 }}$ 
Iwasaki, I., \& Ma, X. (2020). Gender wage gap in China: A large metaanalysis. Journal for Labour Market Research, 54(1), 1-19.

Koirala, G. (2007). An analysis of labour wage differentials in Nepal. Journal of Asian Economics, 18(4), 636-648.

Langdon, D. L., \& Klomegah, R. (2013). Gender wage gap and its associated factors: An examination of traditional gender ideology, education, and occupation. International Review of Modern Sociology, 39(2), 173-203.

Lee, J., \& Ihm, J. (2020). Gender difference in returns to education independent of gender wage gap in Korea. Asian Economic Journal, 34(2), 213-232.

Loewenthal, A., \& Miaari, S. H. (2020). Male-female wage differential in the west bank: A gender-based analysis of the Israeli-Palestinian conflict. Defence and Peace Economics, 31(8), 939-956.

Ma, X. (2021). Ownership sector and the gender wage gap. In Female Employment and Gender Gaps in China, Hitotsubashi University IER Economic Research Series,48, 65-89. Available at: https://doi.org/10.1007/978-98133-6904-7_4

Mincer, J. (1958). Investment in human capital and personal income distribution. Journal of Political Economy, 66(4), 281-302.

Mincer, J. (1962). Labour force participation of married women: A study of labour supply. In Aspects of Labour Economics, NBER, 63-105.

Mincer, J. (1974). Schooling, experience, and earnings. Human Behavior \& Social Institutions, NBER , 2, 71-94.

Mincer, J., \& Polachek, S. (1974). Family investments in human capital: Earnings of women. Journal of Political Economy, 82(2), 76-108.

Nasir, Z. M. (2002). Returns to human capital in Pakistan: A gender disaggregated analysis. The Pakistan Development Review, 41(1) 1-28.

Neuman, S., \& Oaxaca, R. L. (2004). Wage decompositions with selectivitycorrected wage equations: A methodological note. The Journal of Economic Inequality, 2(1), 3-10.

Neumark, D. (1988). Employers' discriminatory behavior and the estimation of wage discrimination. Journal of Human Resources, 23(3) 279-295.

Oaxaca, R. (1973). Male-female wage differentials in urban labour market. International Economic Review, 14(3), 693-709. 
Polachek, S. W. (1975). Potential biases in measuring male-female discrimination. Journal of Human Resources, 10(2), 205-229.

Polachek, S. W. (2004). How the human capital model explains why the gender wage gap narrowed. Institute for the Study of Labour Discussion Paper, 1102.

Qureshi, M. G. (2012). The gender differences in school enrolment and returns to education in Pakistan. The Pakistan Development Review, 84, 219-256.

Razavi, S. M., \& Habibi, N. (2014). Decomposition of gender wage differentials in Iran: An empirical study based on household survey data. The Journal of Developing Areas, 48(2), 185-204.

Sabir, M., \& Aftab, Z. (2007). Dynamism in the gender wage gap: Evidence from Pakistan. The Pakistan Development Review, 46(4), 865-882.

Salari, M., \& Javid, R. J. (2019). How does female labour force participation impact on housing values?. Research in Economics, 73(2), 129-137.

Shabbir, T. (1994). Mincerian earnings function for Pakistan. The Pakistan Development Review, 33(1), 1-18.

Shrestha, B. K., Choi, J. O., Shrestha, P. P., Lim, J., \& Nikkhah Manesh, S. (2020). Employment and wage distribution investigation in the construction industry by gender. Journal of Management in Engineering, 36(4), 0602000106020008.

Sjaastad, L. A. (1962). The costs and returns of human migration. Journal of Political Economy, 70(5), 80-93.

Schirle, T. (2015). The gender wage gap in the Canadian provinces, 1997-2014. Canadian Public Policy, 41(4), 309-319.

Soderbom, M., Teal, F., Wambugu, A., \& Kahyarara, G. (2006). The dynamics of returns to education in Kenyan and Tanzanian manufacturing. Oxford Bulletin of Economics and Statistics, 68(3), 261-288.

Yasin, G., Chaudhry, I., \& Afzal, S. (2010). The determinants of gender wage discrimination in Pakistan: Econometric evidence from Punjab province. Asian Social Science, 6(11), 239-255. 


\section{Appendix}

\begin{tabular}{|c|c|c|c|c|c|c|}
\hline \multicolumn{7}{|c|}{ Appendix A: Overall regression results } \\
\hline Variables & \multicolumn{2}{|c|}{$1997-98$} & \multicolumn{2}{|c|}{$2006-07$} & \multicolumn{2}{|c|}{$2017-18$} \\
\hline $\mathrm{SCH}$ & $.0347 * * *$ & $(22.09)$ & $.0453 * * *$ & $(39.40)$ & $.0302 * * *$ & $(31.35)$ \\
\hline EXP & $.0424 * * *$ & $(13.27)$ & $.0461 * * *$ & $(19.16)$ & $.0348 * * *$ & $(17.40)$ \\
\hline $\mathrm{EXP}^{2}$ & $-.0004 * * *$ & $(-11.09)$ & $-.0005 * * *$ & $(-15.43)$ & $-.0003 * * *$ & $(-13.23)$ \\
\hline TRA & $.0626^{* * *}$ & $(3.34)$ & $.0767 * * *$ & $(2.77)$ & $.0322 * * *$ & $(3.80)$ \\
\hline MIG & $.0865 * * *$ & $(6.46)$ & $.0727 * * *$ & $(6.98)$ & $.0695 * * *$ & (7.85) \\
\hline MAR & $.0551 * * *$ & $(3.50)$ & $.0288 * * *$ & $(2.41)$ & $.0286^{* * * *}$ & $(2.84)$ \\
\hline WHR & $0072 * * *$ & (13.31) & $.0087 * * *$ & $(24.31)$ & $.0128 * * *$ & (39.47) \\
\hline PUB & $.1123 * * *$ & $(9.12)$ & $.3473 * * *$ & (34.94) & $.5473 * * *$ & (58.34) \\
\hline SKL_2 & $.1148 * * *$ & (10.05) & $.1039 * * *$ & (12.03) & $.0585^{* * * *}$ & (7.19) \\
\hline $\mathrm{SKL}^{-} 3$ & $.1083^{*} * *$ & $(5.23)$ & .0099 & $(0.65)$ & $.1423 * * *$ & $(9.07)$ \\
\hline $\mathrm{SKL}_{-} 4$ & $.3392 * * *$ & (15.43) & $.4525 * * *$ & (23.13) & $.2096^{* * *}$ & (14.43) \\
\hline PUN & $-.1020 * * *$ & $(-8.77)$ & $-.0387 * * *$ & $(-4.31)$ & $.0232 * * *$ & $(2.95)$ \\
\hline $\mathrm{KP}$ & $-.1109 * * *$ & $(-7.58)$ & $-.0408 * * *$ & $(-3.49)$ & $.2174 * * *$ & (22.24) \\
\hline BAL & $.0636^{* * *}$ & (4.17) & $.0584 * * *$ & (4.62) & $.2233 * * *$ & (21.03) \\
\hline WLO & $.1262 * * *$ & (11.46) & $.0962 * * *$ & (12.01) & $.1089^{* * *}$ & (15.76) \\
\hline Cons. & 6.2684 & (108.60) & 6.4930 & (158.57) & 7.6581 & (215.37) \\
\hline $\mathrm{N}$ & \multicolumn{2}{|c|}{10,142} & \multicolumn{2}{|c|}{23,317} & \multicolumn{2}{|c|}{30,026} \\
\hline Prob $>F$ & \multicolumn{2}{|c|}{0.0000} & \multicolumn{2}{|c|}{0.0000} & \multicolumn{2}{|c|}{0.0000} \\
\hline R-squared & \multicolumn{2}{|c|}{0.3346} & \multicolumn{2}{|c|}{0.3852} & \multicolumn{2}{|c|}{0.3895} \\
\hline Root MSE & \multicolumn{2}{|c|}{.48239} & \multicolumn{2}{|c|}{.56095} & \multicolumn{2}{|c|}{.54074} \\
\hline
\end{tabular}

Source: Authors own calculation, $\mathrm{z}$-values are in parenthesis, where $* * *, * *, *$ indicates significance at $1 \%, 5 \%$ and $10 \%$ level of significance, respectively.

Appendix B: Results of Blinder-Oaxaca Decomposition (Detailed)

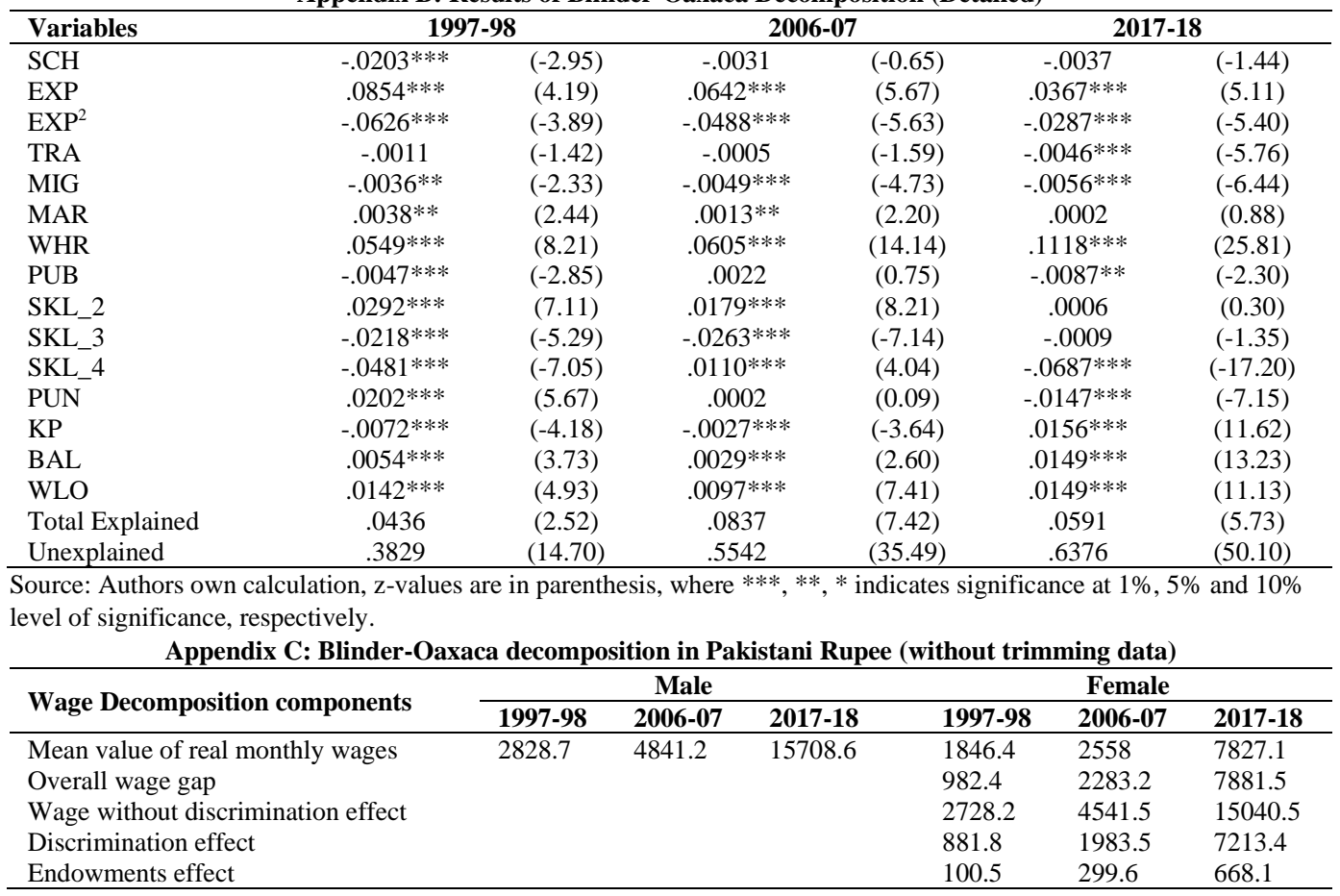

